\title{
Penentuan Kandungan Tanin dan Uji Aktivitas Antioksidan Elkstrak Biji Buah Alpukat (Persea americana Mill.)
}

\author{
Liberty P. Malangngia ${ }^{*}$, Meiske S. Sangia, Jessy J. E. Paendonga \\ aJurusan Kimia, FMIPA, Unsrat, Manado
}

\section{KATA K U N C I}

biji alpukat

tanin

aktivitas antioksidan

\section{K E Y W O R D S}

avocado seed

tannins

antioxidant activity.

\begin{abstract}
A B S TR A K
Penelitian ini bertujuan untuk menentukan kandungan tanin serta menguji aktivitas antioksidan ekstrak biji alpukat segar dan kering. Penentuan kandungan total tanin dilakukan dengan metode Folin Ciocalteau, sedangkan penentuan tanin terkondensasi dilakukan dengan metode Vanilin- $\mathrm{HCl}$ dan aktivitas antioksidan diukur dengan metode DPPH. Hasil yang diperoleh menunjukkan kandungan total tanin biji alpukat biasa kering, biji alpukat mentega kering, biji alpukat biasa segar, biji alpukat mentega segar berturut-turut yaitu $117 \mathrm{mg} / \mathrm{kg}, 112 \mathrm{mg} / \mathrm{kg}$, $41,3335 \mathrm{mg} / \mathrm{kg}$ dan $41 \mathrm{mg} / \mathrm{kg}$. Kandungan tanin terkondensasi biji alpukat biasa kering, biji alpukat mentega kering, biji alpukat biasa segar, biji alpukat mentega segar berturut-turut yaitu 20,855 mg/kg, 16,966 $\mathrm{mg} / \mathrm{kg}, 5,411 \mathrm{mg} / \mathrm{kg}$ dan 4,411 mg/kg. Aktivitas antioksidan tertinggi ditunjukkan oleh ekstrak biji alpukat biasa kering $(93,045 \%)$, diikuti dengan biji alpukat mentega kering (92,970\%), biji alpukat biasa segar $(85,870 \%)$ dan biji alpukat mentega segar $(67,645 \%)$. Biji alpukat memiliki persen aktivitas antioksidan yang tinggi sehingga dapat dipertimbangkan sebagai salah satu sumber antioksidan alami.

\begin{tabular}{l}
\hline A B S T R A C T \\
A research has been conducted to measure the tannins and \\
antioxidant activity of advocado seed fruit extracts. Two types of \\
advocados were used in this research: the ordinary local advocados and \\
the butter local advocados. Folin-Ciocalteu method was used to measure \\
the total tannin compounds, Vanillin- $\mathrm{HCl}$ method was used to measure \\
condensed tannin and DPPH method was used to measure the antioxidant \\
activity. The results showed that the total tannin of the dry ordinary local \\
advocados, dry butter local advocados, fresh ordinary local advocados and \\
fresh butter local advocados were $117 \mathrm{mg} / \mathrm{kg}, 112 \mathrm{mg} / \mathrm{kg}, 41,3335$ \\
mg/kg and $41 \mathrm{mg} / \mathrm{kg}$ respectively. Condensed tannin of the dry ordinary \\
local advocados, dry butter local advocados, fresh ordinary local \\
advocados and fresh butter local advocados were $20,855 \mathrm{mg} / \mathrm{kg}, 16,966$ \\
mg/kg, 5,411 mg/kg and $4,411 \mathrm{mg} / \mathrm{kg}$. The highest antioxidant activity \\
was shown by the extract of dry ordinary local avocado seed ( $93,045 \%)$, \\
then dry butter avocado seed ( $92,970 \%)$, fresh ordinary avocado seed \\
(85,870\%) and fresh butter avocado seed (67,645\%). Avocado seed has \\
high percent of antioxidant activity that can be considered as a source of \\
natural antioxidants.
\end{tabular}
\end{abstract}

enak, buah alpukat juga kaya antioksidan dan zat gizi seperti lemak yaitu 9,8 g/100 g daging buah (Afrianti, 2010).

Sebagian besar masyarakat memanfaatkan alpukat pada buahnya saja sedangkan bagian lain seperti biji kurang dimanfaatkan. Biji alpukat memiliki 
efek hipoglikemik dan dapat digunakan untuk pengobatan secara tradisional dengan cara dikeringkan kemudian dihaluskan, dan air seduhannya dapat diminum. Biji alpukat dipercaya dapat mengobati sakit gigi, maag kronis, hipertensi dan diabetes melitus (Monica, 2006). Beberapa penelitian yang telah dilakukan menunjukkan bahwa biji alpukat memiliki kandungan berbagai senyawa berkhasiat, salah satunya adalah efek antidiabetes melalui kemampuannya menurunkan kadar glukosa darah (Zuhrotun,2007).

Hasil Skrining fitokimia yang dilakukan oleh Zuhrotun (2007) terhadap simplisia dan ekstrak etanol biji alpukat menunjukkan bahwa biji alpukat mengandung polifenol, flavonoid, triterpenoid, kuinon, saponin, tanin dan monoterpenoid dan seskuiterpenoid.

Tanin merupakan senyawa aktif metabolit sekunder yang diketahui mempunyai beberapa khasiat yaitu sebagai astringen, anti diare, anti bakteri dan antioksidan. Tanin merupakan komponen zat organik yang sangat kompleks, terdiri dari senyawa fenolik yang sukar dipisahkan dan sukar mengkristal, mengendapkan protein dari larutannya dan bersenyawa dengan protein tersebut (Desmiaty et al., 2008). Tanin dibagi menjadi dua kelompok yaitu tanin terhidrolisis dan tanin terkondensasi. Tanin memiliki peranan biologis yang kompleks mulai dari pengendap protein hingga pengkhelat logam. Tanin juga dapat berfungsi sebagai antioksidan biologis (Hagerman, 2002).

Antioksidan dalam pengertian kimia, merupakan senyawa pemberi elektron. Antioksidan bekerja dengan cara mendonorkan satu elektronnya kepada senyawa yang bersifat oksidan sehingga aktivitas senyawa oksidan tersebut bisa terhambat. Antioksidan menstabilkan radikal bebas dengan melengkapi kekurangan elektron yang dimiliki radikal bebas, dan menghambat terjadinya reaksi berantai dari pembentukan radikal bebas (Winarsi, 2007). Salah satu metode yang digunakan untuk uji aktivitas antioksidan adalah metode 1,1-difenil-2-pikrilhidrazil (DPPH). Interaksi antioksidan dengan DPPH baik secara transfer elektron atau radikal hidrogen pada $\mathrm{DPPH}$, akan menetralkan karakter radikal bebas dari DPPH dan membentuk DPPH tereduksi. Jika semua elektron pada radikal bebas DPPH menjadi berpasangan, maka warna larutan berubah dari ungu tua menjadi kuning terang dan absorbansi pada panjang gelombang $517 \mathrm{~nm}$ akan hilang (Rohman et al., 2010).

\section{Metode}

\subsection{Alat dan Bahan}

Alat-alat yang digunakan dalam penelitian ini antara lain timbangan analitik, blender, ayakan 65 mesh, oven, desikator, petridish, sudip, batang pengaduk, gelas kimia, gelas ukur, mikropipet, pipet mohr, vortex mixer, labu Erlenmeyer, evaporator, kertas saring, magnetik stirer dan spektrofotometer UV-Vis Milton Roy 501.

Bahan yang digunakan dalam penelitian ini adalah 2 macam biji alpukat. Alpukat pertama adalah alpukat varietas merah bundar atau disebut alpukat biasa memiliki ciri fisik: buah berukuran sedang, kulit buah kasar dan mudah rusak, berwarna merah saat matang, daging buah berserat dan biji buah besar yang selanjutnya disebut alpukat A. Alpukat kedua adalah alpukat varietas hijau panjang atau disebut alpukat mentega memiliki ciri fisik: buah berukuran besar, berwarna hijau kekuningan saat matang, kulit buah licin, daging buah tebal berwarna kuning mentega dan biji buah besar yang selanjutnya disebut sebagai alpukat B. Buah alpukat diperoleh dari perkebunan desa Maumbi Minahasa Utara Sulawesi Utara.

Bahan-bahan kimia yang digunakan yaitu akuades, aluminium foil, etanol 95\%, vanilin $4 \%, \mathrm{HCl}$ pekat, dietil eter, reagen Folin Ciocalteu $50 \%, \mathrm{Na}_{2} \mathrm{CO}_{3}$ 2\% dan 1,1-difenil-2-pikrilhidrazil (DPPH).

\subsection{Prosedur Penelitian}

\subsubsection{Preparasi Sampel Biji Alpukat Kering}

Biji alpukat $A$ dan $B$ dicuci bersih, diiris tipis dan dikering anginkan selama 1 minggu. Setelah kering biji alpukat diblender hingga menjadi serbuk dan diayak dengan menggunakan ayakan 65 mesh.

\subsubsection{Ekstraksi Biji Alpukat}

Ekstraksi sampel dilakukan secara maserasi baik sampel alpukat segar maupun kering. Ditimbang sebanyak $20 \mathrm{~g}$ biji alpukat, direndam dalam $100 \mathrm{~mL}$ etanol 95\% selama 24 jam kemudian disaring sehingga diperoleh filtrat. Perlakuan dilakukan selama 48 jam. Filtrat yang diperoleh disatukan kemudian dievaporasi untuk mendapatkan ekstrak etanol. Ekstrak hasil evaporasi didinginkan dalam desikator sebelum analisis lebih lanjut.

\subsubsection{Penentuan Kadar Air}

Penentuan kadar air dilakukan dengan metode Sudarmadji (1989). Kadar air ditentukan dengan menimbang 2 g biji alpukat. Sampel dimasukkan ke dalam oven pada suhu $105{ }^{\circ} \mathrm{C}$ selama 3 jam, selanjutnya dikeluarkan dari oven dan didinginkan dalam desikator selama 30 menit, kemudian berat sampel ditimbang. Perlakuan ini dilakukan beberapa kali hingga berat sampel konstan.

$$
\% \text { Kadar air }=\frac{\text { berat awal }- \text { berat akhir }}{\text { berat awal }} \times 100 \%
$$

\subsubsection{Penentuan Kandungan Total Tanin}

Kandungan total tanin ditentukan dengan metode Chanwitheesuk et al. (2004) yang sedikit dimodifikasi. Sebanyak 0,5 g biji alpukat diekstraksi dengan $10 \mathrm{~mL}$ dietil eter selama 20 jam, kemudian disaring dan residu yang diperoleh dididihkan dengan $100 \mathrm{~mL}$ akuades selama 2 jam, kemudian didinginkan dan disaring. Ekstrak yang diperoleh ditambahkan dengan akuades hingga volume ekstrak $100 \mathrm{~mL}$. Sebanyak 0,1 mL ekstrak ditambahkan 
dengan 0,1 $\mathrm{mL}$ reagen Folin Ciocalteu dan divortex, ditambahkan dengan $2 \mathrm{~mL} \mathrm{Na}_{2} \mathrm{CO}_{3}$ dan divortex lagi. Absorbansi dibaca pada $\lambda 760 \mathrm{~nm}$ setelah diinkubasi selama 30 menit pada suhu kamar. Hasil yang diperoleh diplotkan terhadap kurva standar asam tanat yang dipersiapkan dengan cara yang sama. Kandungan total tanin dinyatakan dalam mg asam tanat/kg ektrak.

\subsubsection{Penentuan Kandungan Tanin Terkondensasi}

Kandungan tanin terkondensasi ditentukan menurut metode Julkunen-Tiitto dalam Suryanto dan Wehantouw (2009). Sebanyak 0,1 mL larutan ekstrak $200 \mathrm{mg} / \mathrm{L}$ biji alpukat dimasukkan ke dalam tabung reaksi dan dibungkus dengan aluminium foil, kemudian ditambahkan $3 \mathrm{~mL}$ larutan vanilin $4 \%$ (b/v) dalam metanol dan divortex. Selanjutnya ditambahkan 1,5 $\mathrm{mL} \mathrm{HCl}$ pekat dan divortex lagi. Absorbansi dibaca pada $\lambda 500 \mathrm{~nm}$ setelah campuran diinkubasi selama 20 menit pada suhu kamar. Kandungan tanin terkondensasi dinyatakan dalam mg katekin/kg ekstrak.

\subsubsection{Uji Aktivitas Antioksidan}

Uji aktivitas antioksidan dari ekstrak etanol biji alpukat diukur dengan metode Gaulejac et al. dalam Kiay et al. (2011). Sebanyak 0,5 mL ekstrak 200 $\mathrm{mg} / \mathrm{L}$ biji alpukat ditambahkan dengan $2 \mathrm{~mL}$ larutan DPPH dan divortex selama 2 menit. Tingkat berkurangnya warna dari larutan menunjukkan efisiensi penangkap radikal. Absorbansi dibaca dengan spektrofotometer pada $\lambda 517 \mathrm{~nm}$ setelah diinkubasi selama 30 menit. Aktivitas penangkap radikal bebas dihitung sebagai persentase berkurangnya warna DPPH dengan menggunakan persamaan:

Aktivitas penangkap radikal bebas (\%)

$$
=1-\frac{\text { absorbansi sampel }+ \text { kontrol }}{\text { absorbansi kontrol }} \times 100 \%
$$

\section{Hasil dan Pembahasan}

\subsection{Rendemen Ekstrak Biji Alpukat}

Rendemen merupakan persentasi untuk bagian yang dapat diekstrak dari bahan mentah. Besar rendemen hasil ekstraksi $20 \mathrm{~g}$ biji alpukat dalam 100 $\mathrm{mL}$ etanol 95\% dihitung dalam persen rendemen yang dapat dilihat pada Tabel 1.

Data pada Tabel 1 menunjukkan bahwa AK memiliki rendemen yang paling tinggi yaitu $6,248 \%$, selanjutnya BK 5,518\%, AS 4,228\% dan BS 3,124\%. Rendemen hasil yang diperoleh menunjukkan bahwa biji alpukat kering memiliki rendemen yang lebih tinggi dibandingkan dengan biji alpukat segar. Rendemen hasil yang diperoleh tidak menunjukkan perbedaan yang begitu besar hal ini dikarenakan, pelarut yang digunakan sama yaitu etanol. Etanol memiliki sifat polar sehingga komponen-komponen polar dalam biji alpukat dapat diekstraksi dengan pelarut etanol.

Tabel 1 - Rendemen ekstrak biji alpukat segar dan kering.

\begin{tabular}{|l|c|l|}
\hline \multicolumn{1}{|c|}{ Jenis Sampel } & Rendemen (\%) & \multicolumn{1}{c|}{ Warna } \\
\hline Biji alpukat biasa kering (AK) & 6,248 & Merah kecoklatan \\
\hline Biji alpukat biasa segar (AS) & 4,228 & Merah kecoklatan \\
\hline Biji alpukat mentega kering (BK) & 5,518 & Merah kecoklatan \\
\hline Biji alpukat mentega segar (BS) & 3,124 & Merah kecoklatan \\
\hline
\end{tabular}

Tabel 2 - Kadar air biji alpukat segar dan kering.

\begin{tabular}{|l|c|}
\hline \multicolumn{1}{|c|}{ Jenis Sampel } & Kadar Air (\%) \\
\hline Biji alpukat biasa kering (AK) & 12,868 \\
\hline Biji alpukat mentega kering (BK) & 13,494 \\
\hline Biji alpukat biasa segar (AS) & 56,466 \\
\hline Biji alpukat mentega segar (BS) & 59,807 \\
\hline
\end{tabular}

\subsection{Kadar Air Biji Alpukat}

Penentuan kadar air biji alpukat dilakukan untuk mengetahui banyaknya kandungan air dalam biji alpukat segar dan kering. Persentasi kadar air biji alpukat segar dan kering dapat dilihat pada Tabel 2 .

Penentuan kadar air berguna untuk mengetahui ketahanan suatu bahan dalam penyimpanannya dan merupakan cara penanganan terbaik bagi suatu bahan untuk menghindari pengaruh aktivitas mikroba. Tabel 2 menunjukkan bahwa kadar air pada biji alpukat segar lebih tinggi yaitu AS 56,466\% dan BS $59,807 \%$ sedangkan kadar air pada biji alpukat kering yaitu AK 12,868\% dan BK 13,494\%. Jumlah kadar air yang rendah membuat bahan akan lebih tahan disimpan dalam jangka waktu yang relatif lama sehingga kemungkinan rusak karena jamur pada saat penyimpanan sangat kecil. 


\subsection{Penentuan Kandungan Total Tanin}

Tanin secara umum didefinisikan sebagai senyawa polifenol yang memiliki berat molekul cukup tinggi (lebih dari 1000) dan dapat membentuk kompleks dengan protein. Kandungan total tanin ekstrak biji alpukat segar dan kering dapat dilihat pada Gambar 1.

Kandungan total tanin dinyatakan dalam $\mathrm{mg} / \mathrm{kg}$ asam tanat. Gambar 1 menunjukkan bahwa kandungan total tanin tertinggi terdapat pada ekstrak biji alpukat kering. Ekstrak AK memiliki kandungan tanin tertinggi yaitu $117 \mathrm{mg} / \mathrm{kg}$ diikuti ekstrak BK 112 $\mathrm{mg} / \mathrm{kg}$ kemudian ekstrak AS 41,3335 mg/kg dan ekstrak BS $41 \mathrm{mg} / \mathrm{kg}$.. Tanin memiliki aktivitas biologis sebagai antioksidan sehingga kandungan tanin dalam biji alpukat akan berpengaruh terhadap aktivitas antioksidan.

Penentuan kandungan total tanin dalam biji alpukat diuji dengan menggunakan metode fenol total dengan menggunakan pereaksi Folin Ciocalteu dan standar asam tanat. Penentuan fenol total digunakan untuk menentukan kandungan dari senyawa tanin yang terdapat pada setiap sampel. Metode ini mempunyai kelebihan di antaranya penampakan warna yang lebih baik, dapat memperkecil perbedaan pada saat pengujian dan lebih spesifik (Rita, 2006). Metode Folin tidak membedakan antar jenis komponen fenolik. Semakin banyak jumlah gugus hidroksil fenolik, maka semakin besar konsentrasi komponen fenolik yang terdeteksi (Khadambi, 2007).

\subsection{Penentuan Kandungan Tanin Terkondensasi}

Penentuan kandungan tanin terkondensasi diukur dengan menggunakan kurva standar katekin $(\mathrm{mg} / \mathrm{kg})$. Hasil penentuan kandungan tanin terkondensasi ekstrak biji alpukat segar dan kering dapat dilihat pada Gambar 2.

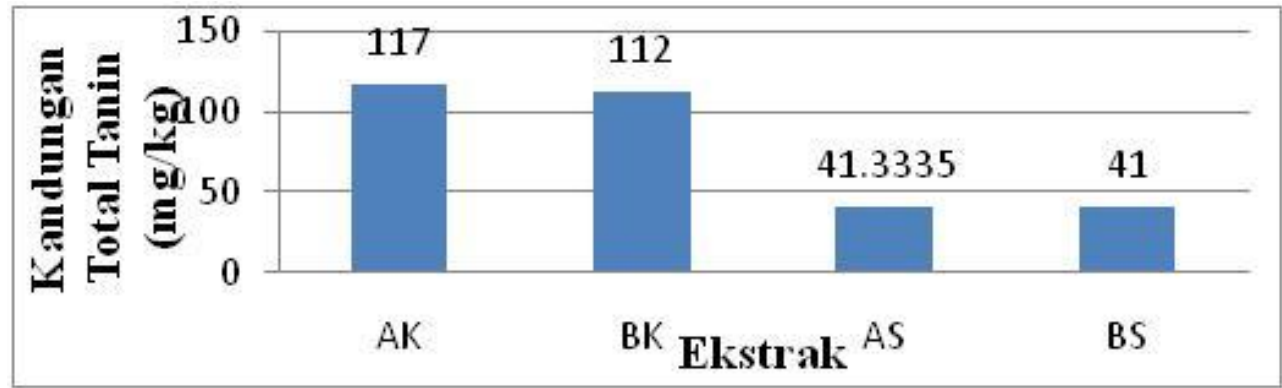

Gambar 1 - Diagram kandungan total tannin ekstrak biji alpukat (AK: biji alpukat biasa kering; BK: biji alpukat mentega kering; AS: biji alpukat biasa segar; BS: biji alpukat mentega segar).

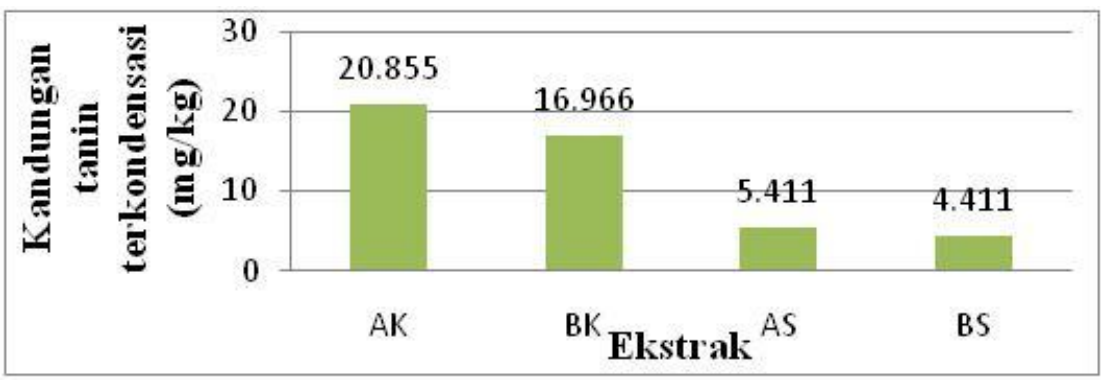

Gambar 2 - Diagram kandungan tanin terkondensasi ekstrak biji alpukat (AK: biji alpukat biasa kering; BK: biji alpukat mentega kering; AS: biji alpukat biasa segar; BS: biji alpukat mentega segar).

Kandungan tanin terkondensasi dalam ekstrak biji alpukat pada Gambar 2 menunjukkan bahwa kandungan tanin terkondensasi pada biji alpukat kering lebih tinggi dibandingkan biji alpukat segar. Berdasarkan hasil yang diperoleh, kandungan tanin terkondensasi tertinggi adalah ekstrak AK 20,855 $\mathrm{mg} / \mathrm{kg}$, ekstrak BK 16,966 mg/kg, ekstrak AS 5,411 $\mathrm{mg} / \mathrm{kg}$ dan ekstrak BS 4,411 mg/kg. Kandungan tanin terkondensasi berkorelasi positif dengan kandungan total tanin. Biji alpukat kering memiliki kandungan tanin yang lebih tinggi dari biji alpukat segar. Kandungan tanin terkondensasi berpengaruh terhadap aktivitas antioksidan karena tanin merupakan salah satu antioksidan alami dalam tumbuhan.

Prinsip uji vanilin- $\mathrm{HCl}$ dalam penentuan kandungan tanin terkondensasi yaitu vanilin terprotonasi dalam asam, membentuk karbokation dan bereaksi dengan flavonoid. Senyawa antara yang dihasilkan mengalami reaksi dehidrasi dan 
menghasilkan senyawa berwarna ungu atau merah (Salunkhe et al.,1990).

\subsection{Uji Aktivitas Antioksidan}

Senyawa radikal bebas biasanya digunakan untuk mengetahui aktivitas penangkap radikal bebas.
Radikal bebas yang digunakan dalam penelitian ini yaitu DPPH. Persentase aktivitas antioksidan dari ekstrak biji alpukat segar dan kering dapat dilihat pada Gambar 3.

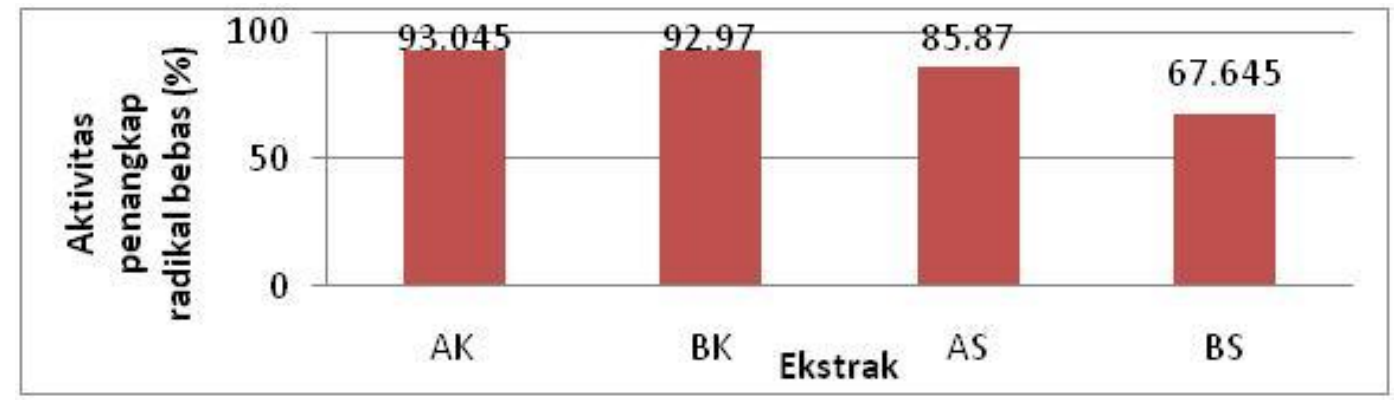

Gambar 3 - Diagram aktivitas antioksidan ekstrak biji alpukat (AK: biji alpukat biasa kering; BK: biji alpukat mentega kering; AS: biji alpukat biasa segar; BS: biji alpukat mentega segar).

Pada saat penambahan larutan DPPH pada sampel biji alpukat, maka terjadi perubahan warna dari ungu menjadi kuning. Intensitas berkurangnya warna diukur absorbansinya pada panjang gelombang $517 \mathrm{~nm}$. Penurunan absorbansi ekstrak menunjukkan peningkatan potensi ekstrak sebagai antioksidan. Gambar 3 menunjukkan bahwa aktivitas penangkap radikal bebas tertinggi yaitu ekstrak AK 93,045\% diikuti ekstrak BK 92,970\% serta ekstrak AS 85,870\% sedangkan ekstrak BS sebesar $67,645 \%$. Hasil tersebut menunjukkan bahwa biji alpukat kering memiliki aktivitas antioksidan yang lebih tinggi daripada yang segar, hal ini berkorelasi positif dengan kandungan tanin dalam ekstrak karena tanin memiliki aktivitas sebagai antioksidan. Semakin banyak kandungan tanin maka semakin besar aktivitas antioksidannya karena tanin tersusun dari senyawa polifenol yang memiliki aktivitas penangkap radikal bebas.

Senyawa yang bereaksi sebagai penangkap radikal akan mereduksi DPPH membentuk DPPH-H yang tereduksi. Reaksi ini diamati dengan adanya perubahan warna DPPH dari ungu menjadi kuning ketika elektron ganjil dari radikal DPPH telah berpasangan dengan hidrogen dari senyawa penangkap radikal bebas (Molyneux, 2004).

\section{Kesimpulan}

Kandungan total tanin ekstrak biji alpukat kering yaitu ekstrak AK 117 mg/kg, ekstrak BK 112 mg/kg dan kandungan tanin terkondensasi ekstrak biji alpukat kering yaitu ekstrak AK 20,855 mg/kg, ekstrak BK 16,966 mg/kg. Kandungan total tanin ekstrak biji alpukat segar yaitu ekstrak AS 41,3335 $\mathrm{mg} / \mathrm{kg}$ dan ekstrak BS $41 \mathrm{mg} / \mathrm{kg}$ dan kandungan tanin terkondensasi ekstrak biji alpukat segar yaitu ekstrak AS 5,411 mg/kg dan ekstrak BS 4,411 $\mathrm{mg} / \mathrm{kg}$.
Aktivitas antioksidan tertinggi biji alpukat ditunjukkan oleh ekstrak biji alpukat biasa kering (AK) yaitu sebesar 93,045\%, kemudian biji alpukat mentega kering (BK) 92,970\%, alpukat biasa segar (AS) $85,870 \%$ dan biji alpukat mentega segar (BS) $67,645 \%$. Biji alpukat memiliki kandungan antioksidan yang relatif tinggi sehingga dapat dipertimbangkan sebagai salah satu sumber antioksidan alami di samping khasiatnya sebagai antidiabetes.

\section{Daftar Pustaka}

Afrianti, L. H. 33 Macam Buah-buahan untuk Kesehatan. Alfabeta. Bandung. 2010.

Chanwitheesuk, A.; Teerawutgulrag A.; Rakariyatham N. Screening of Antioxidant Activity and Antioxidant Compounds of Some Edible Plants of Thailand. Food Chemistry. 2004. 92, 491-497.

Desmiaty, Y.; Ratih H.; Dewi M.A.; Agustin R. Penentuan Jumlah Tanin Total pada Daun Jati Belanda (Guazuma ulmifolia Lamk) dan Daun Sambang Darah (Excoecaria bicolor Hassk.) Secara Kolorimetri dengan Pereaksi Biru Prusia. Ortocarpus. 2008. 8, 106-109.

Hagerman, A. E. Tannin Handbook. Department of Chemistry and Biochemistry, Miami University. 2002.

Khadambi, T. N. Extraction of Phenolic Compounds and Quantification of The Total Phenol and Condensed Tannin Content of Bran Fraction of Condensed Tannin and Condensed Tannin Free Sorghum Varieties. University of Pretoria etd, Pretoria. 2007.

Kiay, N.; Suryanto E.; Mamahit L. Efek Lama Perendaman Ekstrak Kalamansi (Citrus microcarpa) terhadap Aktivitas Antioksidan 
Tepung Pisang Goroho (Musa spp.). Chemistry Progress. 2011. 4, 27-33

Molyneux, P. The Use of the Stable Free Radical Diphenylpicryl-hydrazyl (DPPH) for Estimating Antioxidant Activity. Songklanakarin Journal of Science and Technology. 2004. 26, 211-219.

Monica, F. Pengaruh Pemberian Air Seduhan Serbuk Biji Alpukat (Persea americana Mill) terhadap Kadar Glukosa Darah Tikus Wistar yang diberi Beban Glukosa. Skripsi. Universitas Diponegoro, Semarang. Juli 2006.

Rita, Y. Kandungan Tanin dan Potensi Anti Streptococcus Mutans Daun The Varietas Assamica pada Berbagai Tahap Pengolahan. Skripsi. Institut Pertanian Bogor, Bogor. Juni 2006

Rohman, A.; Riyanto S.; Yuniarti N.; Saputra W.R.; Utami R.; Mulatsih W. Antioxidant Activity, Total Phenolic and Total Flavaonoid of Extracts and Fractions of Red Fruit (Padanus conoideus Lam).
International Food Research Journal. 2010. 17, 97-106.

Salunkhe, D. K.; Chavan J.K.; Kadam S.S. Dietary Tannins Consequences and Remedies. CRC Press, Boca Raton.1990.

Sudarmadji, S.; Haryono B.; Suhardi. Prosedur Analisis untuk Bahan Makanan dan Pertanian. Liberty, Yogyakarta.1989.

Suryanto, E.; Wehantouw F. Aktivitas Penangkap Radikal Bebas dari Ekstrak Fenolik Daun Sukun (Artocarpus Altilis F.). Chemistry Progress. 2009. 2, 1-7

Winarsi, H. Antioksidan Alami dan Radikal Bebas. Kanisius, Yogyakarta. 2007.

Zuhrotun, A. Aktivitas Antidiabetes Ekstrak Etanol Biji Buah Alpukat (Persea americana Mill.) Bentuk Bulat. Universitas Padjadjaran, Bandung. (tidak dipublikasikan) Oktober 2007. 